\title{
Effect of cadmium incorporation on the properties of zinc oxide thin films
}

\author{
S. P. Bharath ${ }^{1} \cdot$ Kasturi V. Bangera ${ }^{1} \cdot$ G. K. Shivakumar ${ }^{2}$
}

Received: 27 September 2017 / Accepted: 11 January 2018 / Published online: 3 February 2018

(c) Springer-Verlag GmbH Germany, part of Springer Nature 2018

\begin{abstract}
$\mathrm{Cd}_{x} \mathrm{Zn}_{1-x} \mathrm{O}(0 \leq x \leq 0.20)$ thin films are deposited on soda lime glass substrates using spray pyrolysis technique. To check the thermal stability, $\mathrm{Cd}_{x} \mathrm{Zn}_{1-x} \mathrm{O}$ thin films are subjected to annealing. Both the as-deposited and annealed $\mathrm{Cd}_{x} \mathrm{Zn}_{1-x} \mathrm{O}$ thin films are characterized using X-ray diffraction (XRD), scanning electron microscope (SEM) and energy-dispersive X-ray analysis (EDAX) to check the structural, surface morphological and compositional properties, respectively. XRD analysis reveals that the both as-deposited and annealed $\mathrm{Cd}_{x} \mathrm{Zn}_{1-x} \mathrm{O}$ thin films are (002) oriented with wurtzite structure. SEM studies confirm that as-deposited, as well as annealed $\mathrm{Cd}_{x} \mathrm{Zn}_{1-x} \mathrm{O}$ thin films are free from pinholes and cracks. Compositional analysis shows the deficiency in Cd content after annealing. Optical properties evaluated from UV-Vis spectroscopy shows red shift in the band gap for $\mathrm{Cd}_{x} \mathrm{Zn}_{1-x} \mathrm{O}$ thin films. Electrical property measured using two probe method shows a decrease in the resistance after $\mathrm{Cd}$ incorporation. The results indicate that cadmium can be successfully incorporated in zinc oxide thin films to achieve structural changes in the properties of films.
\end{abstract}

Keywords $\mathrm{CdZnO} \cdot$ Thin films $\cdot$ Spray pyrolysis technique

\section{Introduction}

Exploration of wide band gap compound semiconductor material produced lot of benefits to human life. Materials like $\mathrm{Al}_{x} \mathrm{Ga}_{1-x} \mathrm{~N}, \mathrm{BN}$ and $\mathrm{ZnO}$ attracted the interest for device applications like UV-LEDs (Kinoshita et al. 2000), lasers (Watanabe et al. 2004) and thin-film transistors (Xu et al. 2016). Among different wide band gap materials, earthabundant $\mathrm{ZnO}$ is a very important material, which finds application in solar cells (Bi et al. 2013). Large exciton binding energy of $60 \mathrm{meV}$, which can be increased up to $100 \mathrm{meV}$ in superlattices, makes it an important candidate for lasers and LEDs (Tsukazaki et al. 2005). ZnO reflects the thermal infrared heat and can be exploited to prepare EMI shielding coatings, and heat/microwave reflecting coatings for windows (Miao et al. 2014). To develop ZnO-based

S. P. Bharath

pbharathbhat@gmail.com

1 Thin Film Laboratory, Department of Physics, National Institute of Technology, Karnataka, Surathkal, Mangalore 575025, India

2 Department of Physics, NMAM Institute of Technology, Nitte 574110, India opto-electronic devices, it is an important requirement to alter the electrical and optical properties. $\mathrm{ZnO}$ is a well known n-type semiconductor material, this n-type conductivity further increased by dopants like In (Pati et al. 2015), $\mathrm{Ga}$ (Chin et al. 2016), Al (Kumar et al. 2014), etc. It is also possible to produce p-type $\mathrm{ZnO}$ by doping $\mathrm{Bi}$ (Sadananda et al. 2013), As (Ryu et al. 2000), P (Kim et al. 2003), etc. Optical band gap of $\mathrm{ZnO}$ can be widened by alloying with $\mathrm{Mg}$, which can reach up to $4.5 \mathrm{eV}$ (Takagi et al. 2003). In addition, band gap can be engineered to lower values using $\mathrm{Cd}$ (Ma et al. 2011). The $\mathrm{ZnO}$ (hexagonal) and $\mathrm{CdO}$ (cubic) have very different crystal structure, and also, low thermodynamic solubility ( $2 \mathrm{~mol} . \%)$ of $\mathrm{CdO}$ in $\mathrm{CdO}-\mathrm{ZnO}$ system make it very difficult to grow single-phase hexagonal $\mathrm{Cd}_{x} \mathrm{Zn}_{1-x} \mathrm{O}$ thin films with high $\mathrm{Cd}$ concentration (Ishihara et al. 2006). Different methods can be employed to grow mixed $\mathrm{Cd}_{x} \mathrm{Zn}_{1-x} \mathrm{O}$ thin films, such as molecular beam epitaxy (Wang et al. 2006), sputtering (Ma et al. 2011), pulsed laser deposition (Makino et al. 2013) and spray pyrolysis (Vijayalakshmi et al. 2008). Compared to different methods, the spray pyrolysis method is simplest industrially applicable method to produce metal oxide thin films. Using spray pyrolysis technique, very large area thin film can be grown with very high growth rate. Until now, very limited number of 
work is done on preparation of $\left[\mathrm{Cd}_{x} \mathrm{Zn}_{1-x} \mathrm{O}(0 \leq x \leq 0.20)\right]$ thin film using spray pyrolysis technique. Thus, the present work focuses on the deposition of $\mathrm{Cd}_{x} \mathrm{Zn}_{1-x} \mathrm{O}$ thin films using spray pyrolysis technique and annealing effect on the properties of $\mathrm{Cd}_{x} \mathrm{Zn}_{1-x} \mathrm{O}$ thin films. Further, both as-deposited and annealed $\mathrm{Cd}_{x} \mathrm{Zn}_{1-x} \mathrm{O}$ thin films are characterized to check phase purity, surface morphology, optical and electrical properties.

\section{Experimental details}

$\mathrm{Cd}_{x} \mathrm{Zn}_{1-x} \mathrm{O}$ thin films are deposited on top of the wellcleaned soda lime glass using spray pyrolysis technique. The precursor materials zinc diacetate dihydrate $\left(\mathrm{Zn}\left(\mathrm{CH}_{3} \mathrm{COO}\right)_{2} \cdot 2 \mathrm{H}_{2} \mathrm{O}\right)$ and cadmium chloride $\left(\mathrm{CdCl}_{2} \cdot 2^{1 / 2} \mathrm{H}_{2} \mathrm{O}\right)$ are dissolved in distilled water at different molar ratio to get $\mathrm{Cd}_{x} \mathrm{Zn}_{1-x} \mathrm{O}(0 \leq x \leq 0.20)$ thin films. The precursor solution atomized using spray nozzle was sprayed at a rate of $2 \mathrm{ml} / \mathrm{min}$ on preheated glass substrate held at optimized temperature of $\sim 400{ }^{\circ} \mathrm{C}$. The distance between the spray nozzle and glass substrate is fixed as $30 \mathrm{~cm}$ and air is used as carrier gas at the pressure of 2 bar. The atomized droplets reach the hot glass substrate and oxidizes on glass substrate to form highly adherent $\mathrm{Cd}_{x} \mathrm{Zn}_{1-x} \mathrm{O}$ thin films.

The thin film thickness is measured using gravimetric method and is maintained $\sim 600 \mathrm{~nm}$. The phase and crystallinity of the $\mathrm{Cd}_{x} \mathrm{Zn}_{1-x} \mathrm{O}$ thin films are analysed using $\mathrm{X}$-ray diffractometer (Rigaku Miniflex 600). The surface morphology and chemical composition of the grown film are analysed using field-emission scanning electron microscope (Carl-Zeiss FE-SEM). The optical transmittance of $\mathrm{Cd}_{x} \mathrm{Zn}_{1-x} \mathrm{O}$ thin films is measured using UV-Vis spectrophotometer (Princeton SpectraPro-2300i). The electrical measurements are carried out using computer-interfaced Keithley source meter.

\section{Results and discussion}

\section{X-ray diffraction}

The XRD studies reveal that prepared $\mathrm{Cd}_{x} \mathrm{Zn}_{1-x} \mathrm{O}$ thin films are polycrystalline in nature. It is observed that films have hexagonal wurtzite structure with preferred orientation along $c$-axis. Sharper peak along (002) plane indicates the good crystallinity of the thin film. The absence of $\mathrm{CdO}$ peak confirms the proper distribution of $\mathrm{Cd}$ throughout the thin film without forming any separate impurity phase. The Cd content dependence of the (002) peak positions of $\mathrm{Cd}_{x} \mathrm{Zn}_{1-x} \mathrm{O}$ thin films are listed in Table 1 . Peak position of pure $\mathrm{ZnO}$ thin film is matching with the standard JCPDS file [Card No. 01-079-020]. With addition of Cd, the (002) peak slightly shifts towards a lower angle, proves the substitution of $\mathrm{Zn}^{2+}$ by $\mathrm{Cd}^{2+}$ atoms. The interplanar distance ' $d$ ' is tabulated in the table, which is calculated from the Bragg's equation (Santhosh et al. 2017):

$2 d_{h k l} \sin \theta=n \lambda$

where $n$ is the order of diffraction, $h k l$ the Miller indices of the plane of diffraction. The cell volume $(v)$ and lattice parameter's ' $a$ ' and ' $c$ ' for hexagonal structure can be calculated from relations (Makino et al. 2013), (Santhosh et al. 2017):

$v=\frac{\sqrt{3}}{2} a^{2} c$

$\frac{1}{d^{2}}=\frac{4}{3} \frac{\left(h^{2}+h k+k^{2}\right)}{a^{2}}+\frac{l^{2}}{c^{2}}$

The estimated cell volume, $a$ - and $c$-lattice parameters using XRD data are plotted as function of Cd concentration, shown in the Fig. 1. When the Cd content increases, a slight increase in interplanar distance, cell volume, aand c-lattice parameter can be observed. Since the cationic radii of $\mathrm{Cd}^{2+}(0.97 \AA)$ is different from that of $\mathrm{Zn}^{2+}$ $(0.74 \AA)$, the crystal show a change. The calculated average grain size is tabulated in Table 1, which shows that the average grain size increases when $\mathrm{Cd}$ concentration increases.

Further, to check thermal stability, all the deposited thin films are subjected to air annealing for $4 \mathrm{~h}$ at $400{ }^{\circ} \mathrm{C}$. Fig. 2 shows the XRD spectrum of annealed thin films with various Cd concentration. The XRD patterns reveal that the annealed films are also hexagonal in crystal structure with polycrystalline nature. It also shows that preferred orientation of deposited $\mathrm{Cd}_{x} \mathrm{Zn}_{1-x} \mathrm{O}$ thin films is unaffected by
Table 1 Structural parameters of $\mathrm{Cd}_{x} \mathrm{Zn}_{1-x} \mathrm{O}$ estimated from XRD

\begin{tabular}{llllllll}
\hline Sample name & \multicolumn{3}{l}{ As-deposited samples } & & \multicolumn{3}{l}{ Annealed samples } \\
\cline { 2 - 3 } & $2 \theta\left(^{\circ}\right)$ & $D(\mathrm{~nm})$ & $d(\AA)$ & & $2 \theta\left(^{\circ}\right)$ & $D(\mathrm{~nm})$ & $d(\AA)$ \\
\hline $\mathrm{ZnO}$ & 34.34 & 24.00 & 2.608 & & 34.33 & 26.00 & 2.608 \\
$\mathrm{Cd}_{0.05} \mathrm{Zn}_{0.95} \mathrm{O}$ & 34.31 & 26.00 & 2.610 & & 34.32 & 28.00 & 2.609 \\
$\mathrm{Cd}_{0.1} \mathrm{Zn}_{0.9} \mathrm{O}$ & 34.24 & 27.00 & 2.618 & & 34.28 & 34.00 & 2.616 \\
$\mathrm{Cd}_{0.2} \mathrm{Zn}_{0.8} \mathrm{O}$ & 34.18 & 26.00 & 2.619 & & 34.21 & 27.00 & 2.617 \\
\hline
\end{tabular}




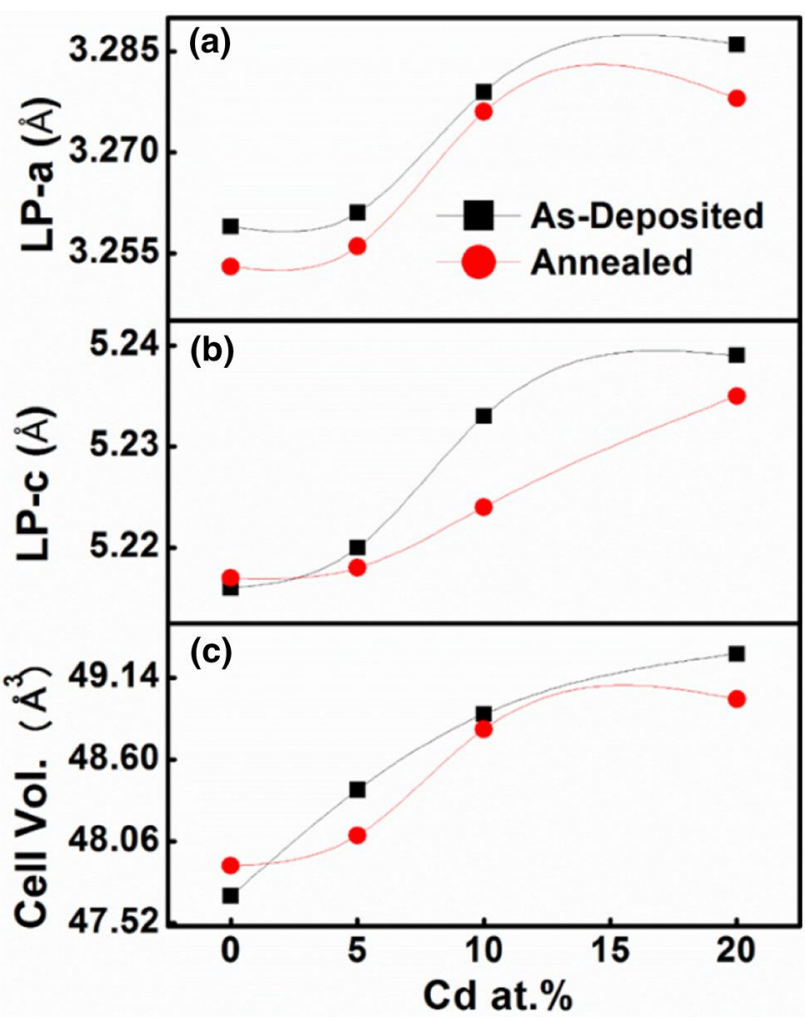

Fig. 1 Cadmium content dependence of a lattice parameter- $a$, b lattice parameter- $c$ and $\mathbf{c}$ cell volume

annealing. From Table 1, it can be observed that the shift in the peak position of (002) plane is less for annealed $\mathrm{Cd}_{x} \mathrm{Zn}_{1-x} \mathrm{O}$ thin films than as-deposited thin films. Figure 1 also shows that the cell volume, $a$ - and $c$-lattice parameters of annealed thin films are reduced as compared with the as-deposited $\mathrm{Cd}_{x} \mathrm{Zn}_{1-x} \mathrm{O}$ thin films. This may be because of reduction in the $\mathrm{Cd}$ concentration, due to re-evaporation during annealing treatment. For all the composition of $\mathrm{Cd}_{x} \mathrm{Zn}_{1-x} \mathrm{O}$ thin films, grain size increases after annealing, which may be because of recrystallization process taking place during annealing.

\section{Scanning electron microscope}

Fig. 3 shows the high-resolution SEM images of the asdeposited $\mathrm{Cd}_{x} \mathrm{Zn}_{1-x} \mathrm{O}$ thin films. It shows that all the thin films are free from pinhole and cracks. It also shows that the films are composed of tightly packed and randomly arranged nanostructures. The as-deposited pure $\mathrm{ZnO}$ thin films consists of arbitrarily arranged nanostructures, which seems like randomly arranged hexagonal platelets, as shown in Fig. 3a. With addition of 5 at.\% Cd, the surface morphology changes to the tightly packed granular structure, which is visible in Fig. 3b. As the Cd concentration is further increased to 10 and 20 at.\%, discrete structure of smaller and larger tightly packed nanostructure can be observed as shown in Fig. 3c, d.

Annealing process changes the microstructure and nature of distribution of the crystallites in the thin films. It also helps proper oxidation of the unreacted metal ions and desorption of gaseous impurities. Fig. 4 shows the SEM images of annealed $\mathrm{Cd}_{x} \mathrm{Zn}_{1-x} \mathrm{O}$ thin films. The plate-like structure of pure $\mathrm{ZnO}$ modifies to randomly shaped granular structure after annealing. In all the remaining samples, recrystallization can be observed clearly, in which smaller clusters are agglomerated to form bigger clusters as shown in Fig. 4.

\section{Elemental analysis}

The compositional studies of prepared $\mathrm{Cd}_{x} \mathrm{Zn}_{1-x} \mathrm{O}$ thin films are carried out using EDX, spectra are shown in Fig. 5. The EDX spectra confirms the presence of $\mathrm{Cd}, \mathrm{Zn}$ and oxygen. Impurities like sodium and silicon, which is from glass substrate also can be observed. It can be observed that the amount of $\mathrm{Cd}$ in prepared $\mathrm{Cd}_{x} \mathrm{Zn}_{1-x} \mathrm{O}$ thin film is less than that in the starting solution. Compositional information of as-deposited thin films are tabulated in Table 2. It is observed that the atomic concentration of $\mathrm{Cd}$ further reduces after annealing because of evaporation of $\mathrm{Cd}$ on annealing. This result is in agreement with XRD analysis.

\section{Optical properties}

The optical transmittance for all the as-deposited $\mathrm{Cd}_{x} \mathrm{Zn}_{1-x} \mathrm{O}$ thin film at room temperature is shown in Fig. 6a. The asdeposited pure $\mathrm{ZnO}$ samples are highly transparent in visible region with transmittance of $>95 \%$. As the Cd concentration increases, the transmittance value decreases and reaches $\sim 60 \%$ at 20 at. $\%$. The decrease in transmittance may be because of increase in surface roughness, which causes the scattering of light and it also may be because of increase in free electron absorption, which is consistent with the decrease in resistivity. The band gap values are determined from plots of $(\alpha h \nu)^{2}$ vs. $(h \nu)$. The band gap value is determined from extrapolation of linear portion of $(\alpha h \nu)^{2}$ to the $(h \nu)$ axis. It is observed that the band gap value decreases as $\mathrm{Cd}$ increases. The obtained band gap values are tabulated in Table 3 . The decrease in band gap values is because of substitution of $\mathrm{Zn}^{2+}$ ions by $\mathrm{Cd}^{2+}$ ions in $\mathrm{ZnO}$ lattice. After annealing, the transmittance value 

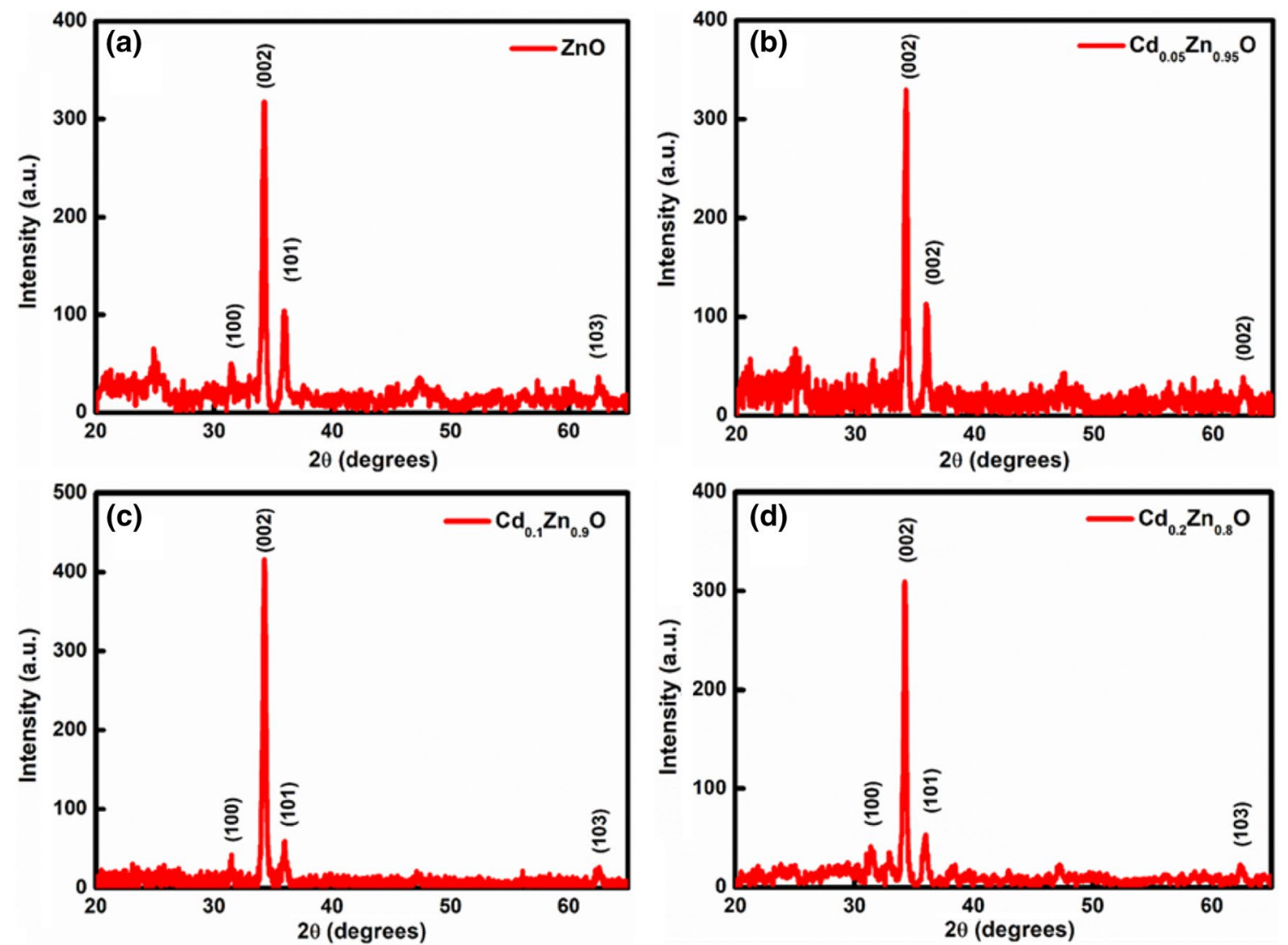

Fig. 2 XRD spectra of annealed $\mathrm{Cd}_{x} \mathrm{Zn}_{1-x} \mathrm{O}$ thin films a $0 \%$, b 5 at. $\%$, c 10 at.\%, d 20 at.\%

Fig. 3 FE-SEM image of asdeposited $\mathrm{Cd}_{x} \mathrm{Zn}_{1-x} \mathrm{O}$ thin films a $0 \%$, b 5 at. $\%$, c 10 at. $\%$ and d 20 at.\%
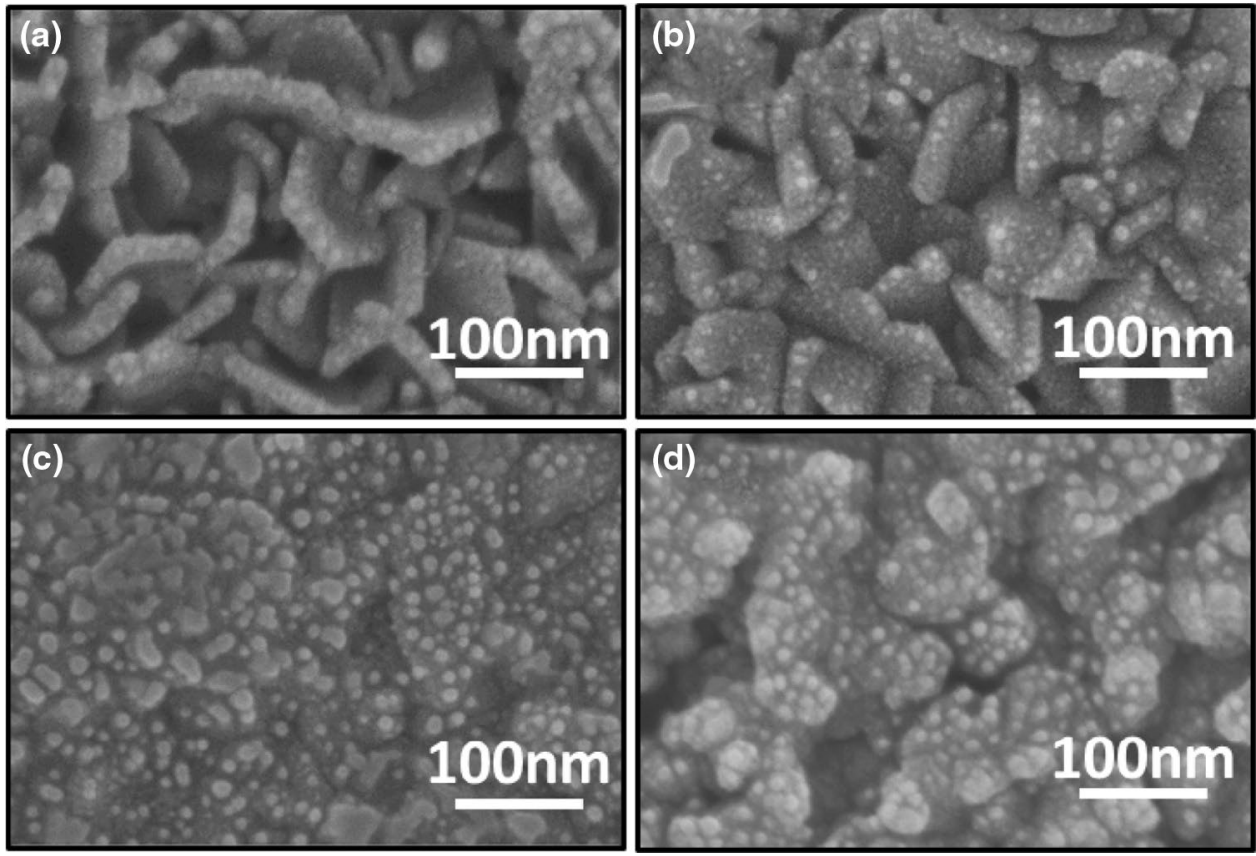
Fig. 4 FE-SEM image of

annealed $\mathrm{Cd}_{x} \mathrm{Zn}_{1-x} \mathrm{O}$ thin films a $0 \%$, b 5 at. \%, c 10 at. $\%$ and d 20 at.\%

Fig. 5 EDAX spectra of annealed $\mathrm{Cd}_{x} \mathrm{Zn}_{1-x} \mathrm{O}$ thin films for different cadmium concentration a $0 \%$, b 5 at.\%, c 10 at.\% and $\mathbf{d} 20$ at. $\%$
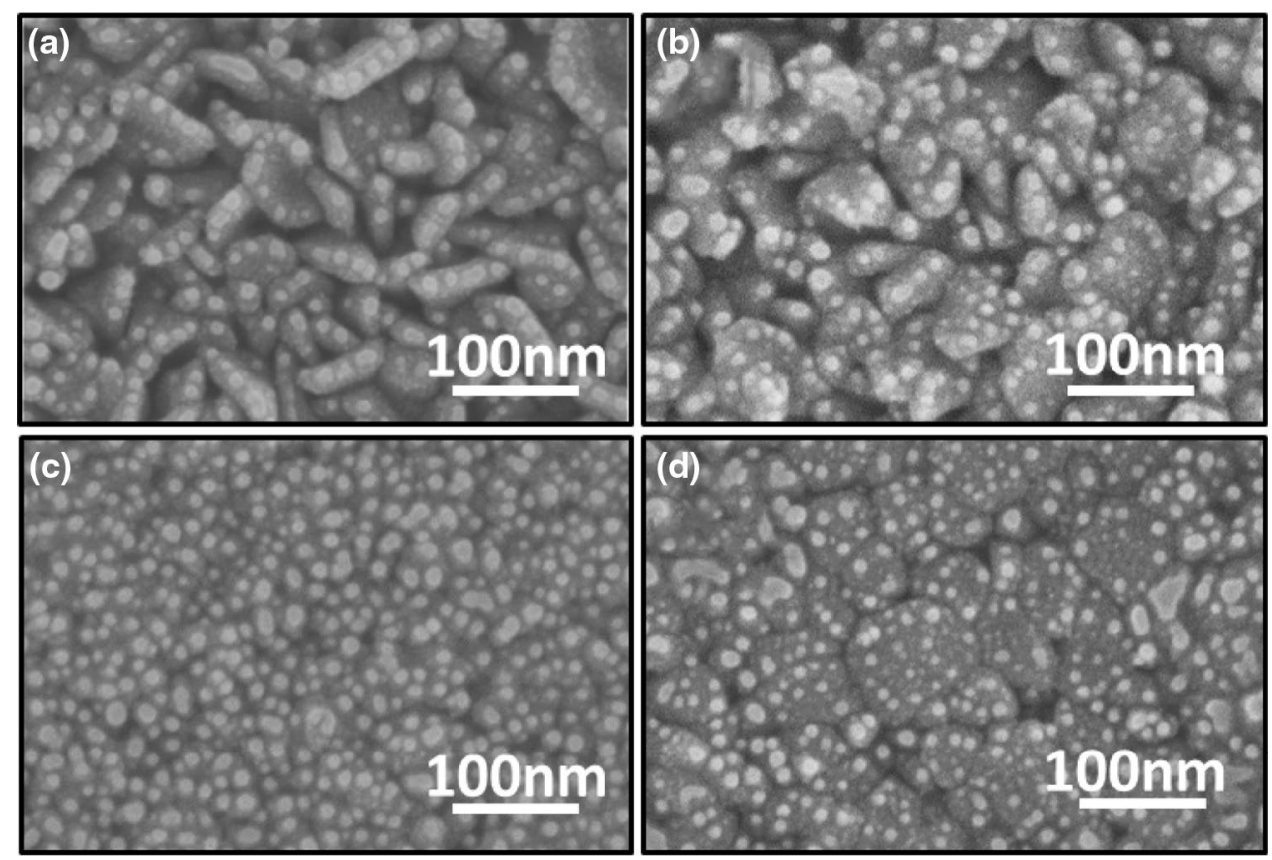

(d)

$100 \mathrm{~nm}$

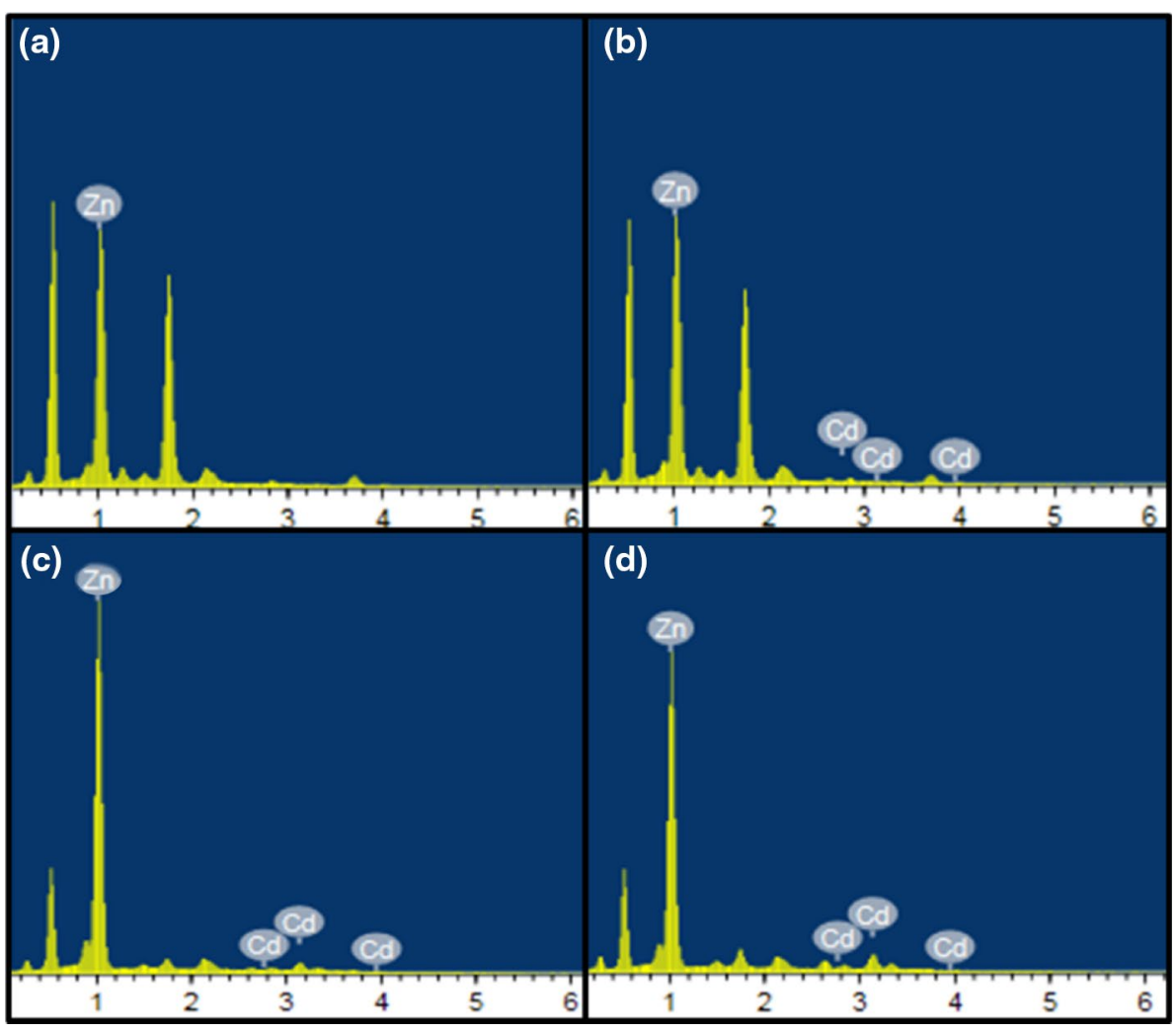


Table 2 Atomic percentage of $\mathrm{Cd}$ and $\mathrm{Zn}$ in $\mathrm{Cd}_{x} \mathrm{Zn}_{1-x} \mathrm{O}$ thin films

\begin{tabular}{llllll}
\hline Sample name & \multicolumn{2}{l}{ As-deposited sample } & & \multicolumn{2}{l}{ Annealed samples } \\
\cline { 2 - 3 } & $\mathrm{Zn}($ at.\%) & Cd (at.\%) & & $\mathrm{Zn}($ at.\%) & Cd (at.\%) \\
\hline $\mathrm{ZnO}$ & 100 & 0 & & 100 & 0 \\
$\mathrm{Cd}_{0.05} \mathrm{Zn}_{0.95} \mathrm{O}$ & 95.45 & 4.54 & & 97.10 & 2.89 \\
$\mathrm{Cd}_{0.1} \mathrm{Zn}_{0.9} \mathrm{O}$ & 92.40 & 7.6 & & 94.45 & 5.55 \\
$\mathrm{Cd}_{0.2} \mathrm{Zn}_{0.8} \mathrm{O}$ & 86.92 & 13.08 & & 88.98 & 10.24 \\
\hline
\end{tabular}

remains almost constant, but slight increase in the band gap is observed. The tauc's plot for annealed $\mathrm{Cd}_{x} \mathrm{Zn}_{1-x} \mathrm{O}$ is shown in Fig. 6b. The slight increase in band gap may be because of evaporation of $\mathrm{Cd}$ from $\mathrm{ZnO}$ lattice, as observed from XRD and EDX analysis.

\section{Electrical properties}

All the as-deposited thin films show n-type conductivity, which is tested using hot-probe experiment. The I-V measurement of thin films with aluminium co-planar contacts shows the linear ohmic nature of the thin film (shown in Fig. 7). The measured resistance, calculated conductivity of the $\mathrm{Cd}_{x} \mathrm{Zn}_{1-x} \mathrm{O}$ thin film is tabulated in Table 4. Conductivity of $\mathrm{Cd}_{x} \mathrm{Zn}_{1-x} \mathrm{O}$ thin film increases with increase in $\mathrm{Cd}$ concentration up to 10 at.\%. The $\mathrm{Cd}$ atom may occupy interstitial position in $\mathrm{ZnO}$ lattice and donates two electrons to conduction band, which is responsible for increase in conductivity. With 20 at.\% Cd concentration, the conductivity decreases, which may be because of decrease in crystallinity, as observed from $\mathrm{XRD}$. After annealing, decrease in the conductivity is
Table 3 Band gap of as-deposited and annealed $\mathrm{Cd}_{x} \mathrm{Zn}_{1-x} \mathrm{O}$ thin films

\begin{tabular}{lll}
\hline Sample name & $\begin{array}{l}\text { As-deposited } \mathrm{Cd}_{x} \mathrm{Zn}_{1-x} \mathrm{O} \\
(\mathrm{eV})\end{array}$ & $\begin{array}{l}\text { Annealed } \\
\mathrm{Cd}_{x} \mathrm{Zn}_{1-x} \mathrm{O} \\
(\mathrm{eV})\end{array}$ \\
\hline $\mathrm{ZnO}$ & 3.27 & 3.30 \\
$\mathrm{Cd}_{0.05} \mathrm{Zn}_{0.95} \mathrm{O}$ & 3.22 & 3.23 \\
$\mathrm{Cd}_{0.1} \mathrm{Zn}_{0.9} \mathrm{O}$ & 3.00 & 3.10 \\
$\mathrm{Cd}_{0.2} \mathrm{Zn}_{0.8} \mathrm{O}$ & 2.83 & 2.87 \\
\hline
\end{tabular}

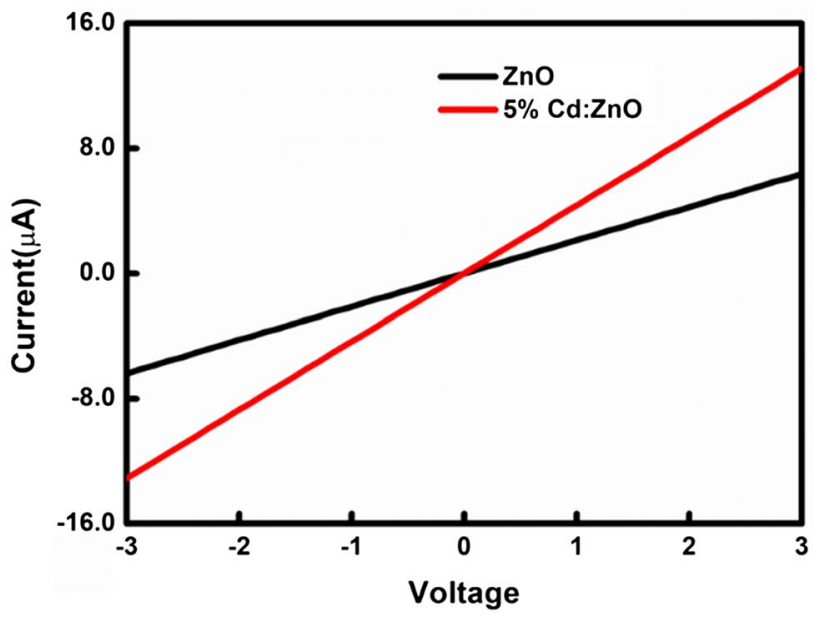

Fig. $7 \mathrm{I}-\mathrm{V}$ characteristic curve of as-deposited $\mathrm{ZnO}$ and $\mathrm{Cd}_{0.05} \mathrm{Zn}_{0.95} \mathrm{O}$ thin films

observed for all the $\mathrm{Cd}_{x} \mathrm{Zn}_{1-x} \mathrm{O}$ thin films. The decrease in the conductivity is because of evaporation of $\mathrm{Cd}$, as observed from EDX analysis.
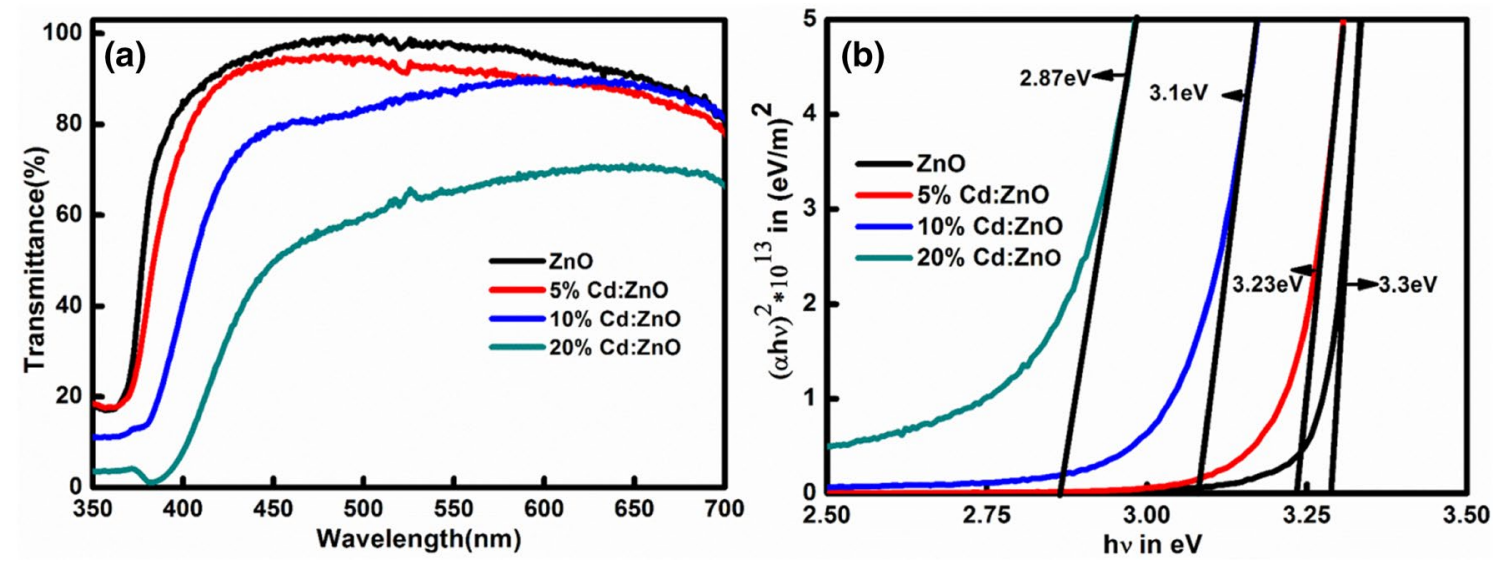

Fig. 6 a Transmittance spectra, b Tauc's plots of annealed $\mathrm{Cd}_{x} \mathrm{Zn}_{1-x} \mathrm{O}$ thin films 
Table 4 Electrical data of as-deposited and annealed $\mathrm{Cd}_{x} \mathrm{Zn}_{1-x} \mathrm{O}$ thin films

\begin{tabular}{llllll}
\hline Sample name & \multicolumn{2}{l}{ As-deposited sample } & & \multicolumn{2}{l}{ Annealed samples } \\
\cline { 2 - 3 } \cline { 6 - 7 } & $\begin{array}{l}\text { Resistance } \\
(\Omega)\end{array}$ & $\begin{array}{l}\text { Conduc- } \\
\text { tivity } \\
(\mathrm{S} / \mathrm{m})\end{array}$ & & $\begin{array}{l}\text { Resistance } \\
(\Omega)\end{array}$ & $\begin{array}{l}\text { Con- } \\
\text { duc- } \\
\text { tivity } \\
(\mathrm{S} / \mathrm{m})\end{array}$ \\
\hline $\mathrm{ZnO}$ & $2.60 \mathrm{M} \Omega$ & 0.05 & $10.8 \mathrm{M} \Omega$ & 0.015 \\
$\mathrm{Cd}_{0.05} \mathrm{Zn}_{0.95} \mathrm{O}$ & $36.0 \mathrm{k} \Omega$ & 3.97 & & $2.5 \mathrm{M} \Omega$ & 0.066 \\
$\mathrm{Cd}_{0.1} \mathrm{Zn}_{0.9} \mathrm{O}$ & $3.69 \mathrm{k} \Omega$ & 38.71 & & $180 \mathrm{k} \Omega$ & 0.925 \\
$\mathrm{Cd}_{0.2} \mathrm{Zn}_{0.8} \mathrm{O}$ & $43.0 \mathrm{k} \Omega$ & 3.32 & & $230 \mathrm{k} \Omega$ & 0.724 \\
\hline
\end{tabular}

\section{Conclusion}

Thin film of $\mathrm{Cd}_{x} \mathrm{Zn}_{1-x} \mathrm{O}(0 \leq x \leq 0.20)$ are deposited on soda lime glass substrates. The deposited films were wurtzite in structure with orientation along (002) direction. The shift in the (002) peak position confirms the incorporation of $\mathrm{Cd}$ in $\mathrm{ZnO}$ lattice. Annealing process does not affect the preferred orientation of the $\mathrm{Cd}_{x} \mathrm{Zn}_{1-x} \mathrm{O}$ thin film. After annealing, slight change in the surface morphology and reduction in $\mathrm{Cd}$ content was observed. Red shift in the band gap values was observed with increase in Cd concentration. It is particularly interesting to note that the electrical conductivity of asdeposited $\mathrm{ZnO}$ thin films increases after $\mathrm{Cd}$ incorporation.

Acknowledgements One of the author Bharath S.P. is grateful to National Institute of Technology, Karnataka and MHRD for financial support throughout research work. Authors are also grateful to DSTPURSE, Mangalore University for providing SEM and EDAX facility.

\section{References}

Bi D, Boschloo G, Schwarzmüller S, Yang L, Johansson EM, Hagfeldt A (2013) Efficient and stable CH3NH3PbI3-sensitized ZnO nanorod array solid-state solar cells. Nanoscale 5:11686-11691. https://doi.org/10.1039/c3nr01542d

Chin HS, Chao LS, Wu CC (2016) Crystal, optical, and electrical characteristics of transparent conducting gallium-doped zinc oxide films deposited on flexible polyethylene naphthalate substrates using radio frequency magnetron sputtering. Mater Res Bull 79:90-96. https://doi.org/10.1016/j.materresbull.2016.03.017

Ishihara J, Nakamura A, Shigemori S, Aoki T, Temmyo J (2006) $\mathrm{Zn}_{1-x} \mathrm{Cd}_{x} \mathrm{O}$ systems with visible band gaps $\mathrm{Zn}_{1-x} \mathrm{Cd}_{x} \mathrm{O}$ systems with visible band gaps. Appl Phys Lett 91914:10-12. https://doi. org/10.1063/1.2345232

Kim KK, Kim HS, Hwang DK, Lim JH, Park SJ (2003) Realization of p-type $\mathrm{ZnO}$ thin films via phosphorus doping and thermal activation of the dopant realization of p-type $\mathrm{ZnO}$ thin films via phosphorus doping and thermal activation of the dopant. Appl Phys Lett 63:1-4. https://doi.org/10.1063/1.1591064

Kinoshita A, Hirayama H, Ainoya M, Aoyagi Y, Hirata A (2000) Room-temperature operation at $333 \mathrm{~nm}$ of Al $0.03 \mathrm{Ga} 0.97 \mathrm{~N} /$
Al 0.25 Ga $0.75 \mathrm{~N}$ quantum-well light-emitting diodes with $\mathrm{Mg}$ doped superlattice layers. Appl Phys Lett 175:75-78. https://doi. org/10.1063/1.126915

Kumar NS, Bangera KV, Shivakumar GK (2014) Properties of nanostructured $\mathrm{Al}$ doped $\mathrm{ZnO}$ thin films grown by spray pyrolysis technique. Semiconductors 48:1023-1027. https://doi.org/10.1134/ s106378261408017x

Ma X, Chen P, Zhang R, Yang D (2011) Optical properties of sputtered hexagonal $\mathrm{CdZnO}$ films with band gap energies from 1.8 to 3.3 eV. J Alloy Compd 509:6599-6602. https://doi.org/10.1016/j.jallc om.2011.03.101

Makino T, Segawa Y, Kawasaki M, Ohtomo A, Shiroki R, Tamura K, Yasuda T, Koinuma $H$ (2013) Band gap engineering based on $\mathrm{Mg}_{x} \mathrm{Zn}_{1-x} \mathrm{O}$ and $\mathrm{Cd}_{y} \mathrm{Zn}_{1-y} \mathrm{O}$ ternary alloy films alloy films. Appl Phys Lett 1237:1-4. https://doi.org/10.1063/1.1350632

Miao D, Jiang S, Shang S, Chen Z (2014) Effect of heat treatment on infrared reflection property of Al-doped $\mathrm{ZnO}$ films. Sol Energ Mat Sol C 127:163-168

Pati S, Banerji P, Majumder SB (2015) Properties of indium doped nanocrystalline $\mathrm{ZnO}$ thin films and their enhanced gas sensing performance. RSC Adv 5(75):61230-61238. https://doi. org/10.1039/c5ra10919a

Ryu YR, Zhu S, Look DC, Wrobel JM, Jeong HM, White HW (2000) Synthesis of p-type ZnO films. J Cryst Growth 216:330-334

Sadananda N, Bangera KV, Anandan C, Shivakumar GK (2013) Properties of $\mathrm{ZnO}$ : $\mathrm{Bi}$ thin films prepared by spray pyrolysis technique. J Alloy Compd 578:613-619. https://doi.org/10.1016/j.jallc om.2013.07.036

Santhosh TCM, Bangera KV, Shivakumar GK (2017) Band gap engineering of mixed $\mathrm{Cd}_{1-\mathrm{x}} \mathrm{Zn}_{\mathrm{x}}$ Se thin films. J Alloy Compd 703:40-44

Takagi T, Tanaka H, Fujita S, Fujita S (2003) Molecular beam epitaxy of high magnesium content single-phase wurtzite $\mathrm{Mg}_{x} \mathrm{Zn}_{1-x} \mathrm{O}$ alloys $(x \simeq 0.5)$ and their application to solar-blind region photodetectors. Jpn J Appl Phys 401:2-5. https://doi.org/10.1143/ jjap. 42.1401

Tsukazaki A, Ohtomo A, Onuma T, Ohtani M, Makino T, Sumiya M, Ohtani K, Chichibu SF, Fuke S, Segawa Y, Ohno H (2005) Repeated temperature modulation epitaxy for p-type doping and light-emitting diode based on $\mathrm{ZnO}$. Nat Mater. https://doi. org/10.1038/nmat1284

Vijayalakshmi S, Venkataraj S, Jayavel R (2008) Characterization of cadmium doped zinc oxide $(\mathrm{Cd}: \mathrm{ZnO})$ thin films prepared by spray pyrolysis method. J Phys D Appl Phys. https://doi. org/10.1088/0022-3727/41/24/245403

Wang XJ, Buyanova IA, Chen WM, Izadifard M, Rawal S, Norton DP, Pearton SJ, Osinsky A, Dong JW, Dabiran A (2006) Band gap properties of $\mathrm{Zn}_{1-x} \mathrm{Cd} x \mathrm{O}$ alloys grown by molecular-beam epitaxy. Appl Phys Lett 151909:1-4. https://doi.org/10.1063/1.23610 81

Watanabe K, Taniguchi T, Kanda H (2004) Direct-bandgap properties and evidence for ultraviolet lasing of hexagonal boron nitride single crystal. Nat Mater 3(6):404. https://doi.org/10.1038/nmat1134

Xu L, Chen Q, Liao L, Liu X, Chang TC, Chang KC, Tsai TM, Jiang C, Wang J, Li J (2016) Rational hydrogenation for enhanced mobility and high reliability on ZnO-based Thin film transistors: from simulation to experiment. ACS Appl Mater Inter. https://doi. org/10.1021/acsami.5b10220

Publisher's Note Springer Nature remains neutral with regard to jurisdictional claims in published maps and institutional affiliations. 